\title{
PERCEIVED ORGANISATIONAL SUPPORT AS A MODERATOR IN THE RELATIONSHIP BETWEEN ORGANISATIONAL JUSTICE AND AFFECTIVE ORGANISATIONAL COMMITMENT
}

\author{
Evelyn Twumasi' ${ }^{1}$, BelindaAddo ${ }^{2}$ \\ ${ }^{1}$ University of Education, Winneba, Ghana, etwumasi@uew.edu.gh \\ ${ }^{2}$ Pentecost University College, Ghana, baddo@pentvars.edu.gh
}

\begin{abstract}
Purpose. This study aimed to explore the relationship between organisational justice and commitment and how the combined influence of organisational justice and perceived organisational support (POS) impacts on commitment.
\end{abstract}

Research Methodology. Data were obtained through questionnaires administered to 124 teaching and nonteaching staff, who were conveniently selected by the researchers from Ghanaian public universities. Descriptive survey design was adopted for this study.

Findings. The results from regression analysis of data collected showed a significant positive relationship among the dimensions of organisational justice and affective commitment. Furthermore, POS was found to moderate the relationship between organisational justice and commitment, as the effect of justice on commitment increased when POS was added to the model.

Practical Implications. The present study supported the expected relationship among justice, POS and organisational commitment and implied that higher level of fairness and support from the organisation can favourably influence the commitment level of employees.

Originality. The current research examines the moderating role of POS on organisational justice-commitment link using samples from the Ghanaian higher education institutions. Thus, it makes relevant contribution to the existing literature by modelling both organisational justice and support and analysing its effect on organisational commitment.

Keywords: Organisational justice; perceived organisational support (POS); affective commitment

JEL codes: M1

\section{Introduction}

Organisations all over the world are troubled with generating policies and protocols that allow their staff to be involved and inspired as well as willing to stay. To be able to achieve such important effects, the starting point of most organisational research has focused on organisational leadership, human resource management as well as organisational culture, so as to warrant the right treatment of employees in accordance with standard labour and anti-discriminatory laws. According to Cropanzano et al. (2007), a key model relating to this line of thought is the notion of organisational justice at the workplace, which explicitly states the ways and manner of doing things in the workplace are thought of being fair by its human resources. It has been reported in literature that perceptions of organisational justice have constantly been related to organisational outcomes by researchers (Colquitt et al., 2001). For instance, Cohen-Charash and Spector (2001) reported that perception of justice and equal right makes employees satisfied with their job, show increased commitment as well as reduce turnover rate, and get actively involved in citizenship behaviours (Chen et al., 2008), and safety policies at the workplace are well obeyed (Gyekye \& Haybatolahi, 2015). On the other hand, employees who had been treated unfairly in the organisation showed reduced satisfaction with their job, management mistrust and their commitment levels in the organisation were poor (Ambrose \& Schminke, 2009; Beugre \& Baron, 2001; Brockner, 2002; Chen et al., 2008; Rego \& Cunha, 2010). 
Most of these researchers have used the social exchange theory in providing the rationale for organisational justice and its related outcomes (Blau, 1964; Gloulder, 1960).

The social exchange theory, operating on the basis of reciprocity, explains that employees' perception of fair treatment causes them to feel obligated to recompense their employing institutions with positive behaviours. However, when employees experience unfair treatment, they exhibit negative behaviour, which impacts the organisation. Adopting social exchange theory in this current study, it may be stated that employees may demonstrate increased commitment to the organisation in exchange for the fair treatment received. Perceptions of fairness by employees are a key determinant of behaviour in an organisation.

With respect to the aforementioned theory, measures undertaken in an organisation have significant implications on employee behaviour. Astonishingly, how the perceptions of organisation justice and work environment factors (perceived organisational support [POS]) together affect the behaviour of employees (commitment) is sparsely explored in sub-Saharan Africa, especially in Ghana.

Two probable means in which examination of the joint effect of organisational justice and POS is relevant are explained in this study. In the first scenario, organisational justice and the work environment features have improved outcomes. In that, aside the role played by perception of justice in employees' behaviour as indicated in literature, other work environment features like POS when added to justice could lead to an increased impact on work-related outcomes. Secondly, work environment features and organisational justice lead to replicative outcomes, which becomes possible if justice has partial dependency on employees' perception of the work environment.

Therefore, the aim of this study is to examine the moderating role of POS on organisational justicecommitment link using samples from higher education institutions.

\section{Literature Review}

Overall, Bartlett (2001) thought of organisational commitment to mean the level of attachment felt towards the organisation in which one works for. Thus, it could be inferred that individuals committed to their organisation believe in the course being chartered by their employers, such that they have a strong will not to turnover, but are passionate about exerting additional energy for the well-being of their institution. Organisational commitment is a manifestation of an individual's existence as a person characterised by a strong belief in and acceptance of the organisation's goals and values, a willingness to exert considerable effort on behalf of the organisation and a definite desire to maintain organisational membership. Committed workers contribute more to the organisation than less-committed ones because of their ownership of the goals of the organisation which makes them work hard in pursuit of business objectives. Originally, Mowday et al. (1979) reported organisational commitment as a unidimensional construct which was measured with a single scale. However, Meyer and Allen (1997) reported that commitment is multidimensional in nature and constitutes three components: affective, continuance and normative commitment, described as an emotional attachment, identification and association of an employee with the organisation in which he/she is working. Meyer and Allen (1991) defined the three components of commitment as: 'affective commitment relating to the psychological attachment to an organization, continuance commitment refers to the costs associated with leaving the organization, and normative commitment associated with the perceived obligation to remain with the organization'.

Review of literature (Colquitt et al., 2001; Meyer et al., 2002) indicated an established relationship between perceptions of organisational justice and organisational commitment from different contexts and geographical locations. With regard to the justice-consequence relationship, Colquitt et al. conducted a meta-analytic review of 25 years of organisational justice research and reviewed 183 studies in 2001. Their results showed an overall and unique relationship among distributive, procedural, interpersonal and informational justice and several organisational outcomes of which organisational commitment was a part. Gyekye and Haybatollahi (2015b) supported the impact that justice had on organisation outcome when in their study on organisational justice, a cross-national comparative study of Ghanaian industrial workers and their Finnish counterparts made the assertion that from previous research works, employees who are optimistic about fairness in their workplaces demonstrates more commitment as well as loyalty to their organisations, and obey safety policies. 
The findings of other researchers also provided support for a positive significant relationship between organisational justice and commitment. For instance, Ajala (2015) studied the influence of organisational justice on employees' commitment in manufacturing firms in Oyo State, Nigeria and the implications of industrial social work and reported that all the three dimensions of justice were significantly related to organisational justice. Jointly, the independent variables $(F=163.165 ; p<0.05)$ significantly predicted the dependent variable. The results from the studies portray the need for managers to pay attention to fairness in treating employees at the workplace in order to get employees committed to the course being championed by the organisation. It is essential to have committed employees as it has so many benefits: employees become more loyal and have strong will to stay and see the organisation achieve its objectives, and they are more engaged to the organisation, which ultimately leads to improved productivity and thus organisational growth. Further, in demonstrating that organisational justice is a factor that aids in employee commitment at the workplace, Fatt et al. (2010) analysed the impact of distributive and procedural justice on organisational commitment from the Malaysian companies' perspectives and found a positive significant relationship among the various dimensions of organisational justice and commitment. This implies that to influence a positive attitude and behaviour among employees, it is essential for organisations to develop policies that ensure fair treatment in procedures used in handling and deciding on the outcomes for employees. However, research findings from Lee et al. (2017) demonstrated a different perspective on the justice-commitment nexus. The study predicted organisational justice with the three dimensions of organisational commitment, where interpersonal justice related positively and significantly with affective commitment, whereas it had an inverse relationship with continuance commitment. Meanwhile, distributive justice only predicted normative commitment. A comprehensive empirical research by Perreira et al. (2018) studied the relationship among interpersonal justice, affective commitment and turnover intentions and reported that interpersonal justice is positively related to affective commitment. In corroborating the assertion that organisational justice has influence on commitment, Edeh and Ugwu (2019) investigated the relationship between organisational justice and employee commitment of private secondary school teachers in Nigeria using survey design. The study concluded that organisational justice measured in terms of distributive justice, procedural justice and interactional justice enhances employee commitment in selected private secondary schools in Nigeria.

POS denotes workers' general perceptions regarding their management's contributions and concern for their well-being (Eisenberger et al., 1990). There exist some previous studies (e.g. Kim, 2009; Jordan et al., 2008; Pack, 2005; Pack et al., 2007; Lee et al., 2017) on POS-commitment nexus, but subjects were from different national cultures and context. For instance, Pack et al. (2007) researched on POS, employee satisfaction and retention of student workers in recreational sports department from MidWestern University and reported that POS has significant relationship with affective commitment, normative commitment and job satisfaction, with $46.2 \%$ of affective commitment, $39 \%$ of normative commitment and $53.3 \%$ of job satisfaction being explained by POS. These results implied that exchange relationships do exist for student workers of recreational sports departments (Lee et al., 2017). Evidence for a positive link of POS with affective organisational commitment has well been established in various research works. For instance, Rhoades et al. (2002) have made known using a cross-lagged panel design that POS is positively related to changes in affective organisational commitment over time. These results are an indication that institutions that provide support for their staff will reap the benefits of having employees who are committed to the course of the institution.

Since literature has indicated organisational justice predicts organisational commitment and POS also predicts organisational commitment, it is expected that together, the presence of both variables would be able to better predict organisational commitment. Thus, to authenticate this assertion, the study has the following hypotheses: 
1. There will be a significant positive relationship between organisational justice and affective commitment:

1a. Distributive justice would significantly predict affective commitment

1b. Procedural justice would significantly predict affective commitment

1c. Interactional justice would significantly predict affective commitment

2. POS would moderate the organisational justice and affective commitment nexus.

The conceptual framework is used to represent the formulated hypotheses:

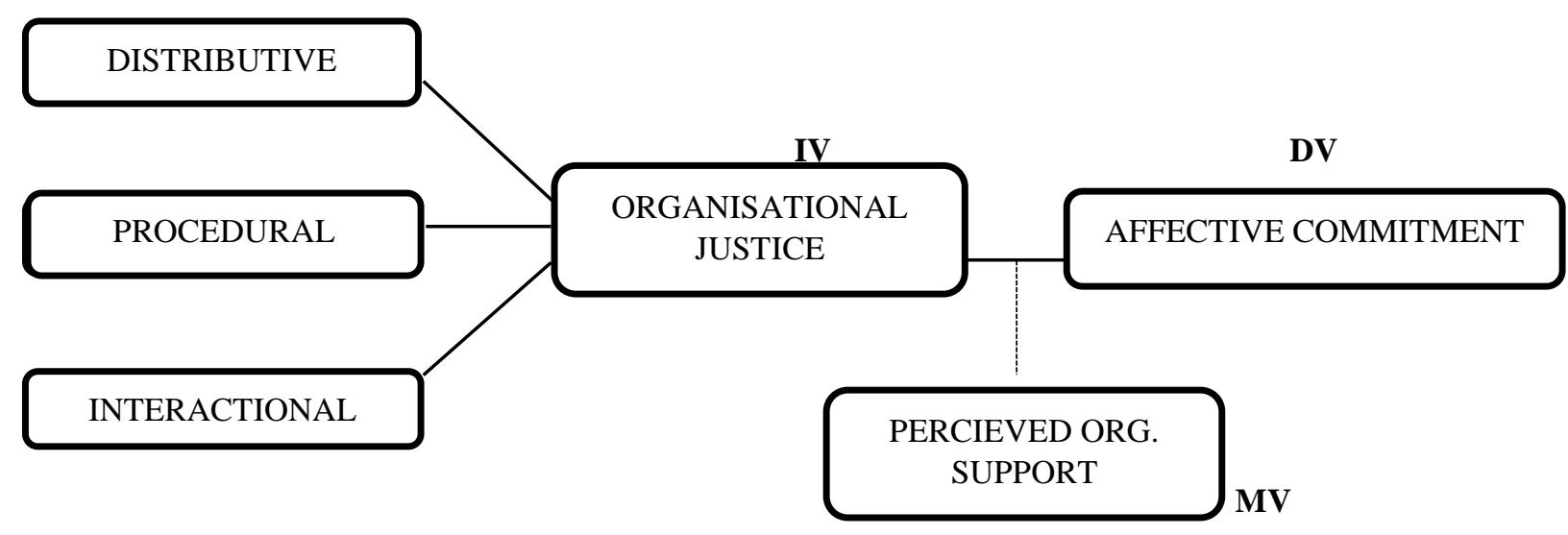

IV = independent variable; $\mathrm{DV}=$ dependent variable $; \mathrm{MV}=$ moderating variable

Fig. 1 Conceptual Framework (Source: authors' developed)

\section{Methodology}

The study participants were selected from three public universities in Ghana. The three universities were chosen based on their similarities in structure and operation. Conveniently, questionnaires were administered to 200 participants. Out of the 200 questionnaires delivered, 124 were returned $(\mathrm{N}=124)$. Majority of the respondents were within the age range of 34-40 years; $66.1 \%$ of them were male and $33.9 \%$ were female. In total, $49.4 \%$ of the sample group had more than 5 years of experience in the university. Additionally, 21.8\% were teaching staff, while $79.2 \%$ were nonteaching staff employees of the universities.

In the words of Eisenberger et al. (1990), POS constitutes workers' general perceptions regarding their management's contributions and concern for their well-being. In this study, POS was measured with the short version of Eisenberger et al.'s (1990) scale. The scale consisted of eight items and assessed workers' evaluations of organisational issues that affected their well-being. Sample items were 'The organisation values my contribution to its well-being' and 'Help is available from the organisation when 1 have a problem'. The total coefficient alpha score was .97 .

Organisational justice was measured with the scale of Colquitt (2001). The instrument had 15 items and measured respondents' views of fairness in three proportions: (i) distributive justice (sample item: 'My work load and responsibilities are fair': $\alpha=.84$ ); (ii) procedural justice (sample item: 'All job decisions are applied consistently to all workers': $\alpha=.93$ ) and (iii) interactional justice (sample item: 'When decisions are made about my job, my supervisor shows concern for my rights as an employee': $\alpha=.93$ ).

To ascertain affective commitment, Allen et al.'s (1993) measure was adopted. The affective commitment had six items (e.g. I feel a strong sense of belonging to my organisation; $\alpha=.82$ ).

Moderated hierarchical regression analyses were undertaken by the researchers to assess the nature and strength of the associations among distributive justice, procedural justice, interactional justice, POS and 
the dependent variable, that is, affective commitment. Initially, the identified controlled variables were entered into the process. Subsequently, the main effects for distributive justice, procedural justice, interactional justice and POS were added to the process. The researchers entered the three different twoway interactions between the centred variables entered in the second step in the third stage. To end the analysis in the fourth step, the three-way interaction term between the centred variables was added.

Before analysis, the data collected were checked for completeness and consistency. A regression model was used to analyse the data collected from the questionnaires to establish the relationship between organisational justice dimensions and organisational commitment dimensions. However, the moderating role of the POS in the organisational justice and commitment nexus was analysed using moderated regression analysis by Hayes (2013).

\section{Results}

IBM's Statistical Package for Social Sciences (SPSS) version 22.0 was used for data analysis. The statistical tests employed included Pearson product moment correlation coefficient and hierarchical multiple regression analyses. An alpha level of .05 was assumed for all the tests. Prior to the hierarchical regression, Pearson correlation was conducted to explore the relationship among the study variables as shown in Table 1. Affective organisational commitment correlated with distributive justice $(r=.427, p$ $<.001)$, procedural justice $(r=.345, p<.001)$, interactional justice $(r=.502, p<.001)$ and POS $(r=$ $.570, p<.001)$. Distributive justice was related to procedural justice $(r=.599, p<.001)$, interactional justice $(r=.565, p<.001)$ and POS $(r=.572, p<.001)$. Procedural justice correlated with interactional justice $(r=.501, p<.001)$ and POS $(r=.622, p<.001)$. Finally, interactional justice was related to POS $(r=.592, p<.05)$. Therefore, the correlational analyses results suggest that in general, the variables in our study were significantly correlated in the expected directions. Further, the correlation coefficients among the study constructs did not exceed .85 , indicating that multicollinearity is not a problem (Kline, 2005).

Table 1: Results of Pearson correlation (Source: authors' compilation)

\begin{tabular}{|l|l|l|l|l|l|l|l|l|l|}
\hline & Gender & Age & Tenure & Status & $\begin{array}{l}\text { Affective } \\
\text { Commitment }\end{array}$ & $\begin{array}{l}\text { Distributive } \\
\text { justice }\end{array}$ & $\begin{array}{l}\text { Procedural } \\
\text { justice }\end{array}$ & $\begin{array}{l}\text { Interactional } \\
\text { justice }\end{array}$ & $\begin{array}{l}\text { Perceived } \\
\text { organisational } \\
\text { support }\end{array}$ \\
\hline Gender & 1 & .150 & .415 & .250 & .151 & .092 & .069 & .089 & .047 \\
\hline Age & & 1 & $.506^{*}$ & $\begin{array}{l}- \\
.268^{* *}\end{array}$ & $-.222^{*}$ & .183 & .061 & -.098 & .159 \\
\hline Tenure & & & 1 & $.186^{*}$ & .075 & -.012 & .042 & .059 & .178 \\
\hline Status & & & & 1 & $.396^{* *}$ & $.416^{* *}$ & $.238^{* *}$ & $.408^{* *}$ & $.510^{* *}$ \\
\hline $\begin{array}{l}\text { Affective } \\
\text { commitment }\end{array}$ & & & & & 1 & $.427^{* *}$ & $.345^{* *}$ & $.502^{* *}$ & $.570^{* *}$ \\
\hline $\begin{array}{l}\text { Distributive } \\
\text { justice }\end{array}$ & & & & & & 1 & $.599^{* *}$ & $.565^{* *}$ & $.572^{* *}$ \\
\hline $\begin{array}{l}\text { Procedural } \\
\text { justice }\end{array}$ & & & & & & & 1 & .501 & $.622^{* *}$ \\
\hline $\begin{array}{l}\text { Interactional } \\
\text { justice }\end{array}$ & & & & & & & & 1 & $.592^{* *}$ \\
\hline $\begin{array}{l}\text { Perceived } \\
\text { organisational } \\
\text { support }\end{array}$ & 1 & .150 & .415 & .250 & .151 & .092 & .069 & .089 & .047 \\
\hline
\end{tabular}

$* *=\mathrm{p}<0.01 ; * \mathrm{p}<.05$ 
Table 2: Results from hierarchical moderated regression analyses (Source: authors' compilation)

\begin{tabular}{|c|c|c|c|c|}
\hline & $\begin{array}{l}\text { DV = affective } \\
\text { commitment }\end{array}$ & & & \\
\hline Predictors & $R^{2}$ & $R^{2}$ change & $F$ & Beta \\
\hline Step 1: Control variables & .245 & .245 & $10.309 *$ & \\
\hline Gender & & & & $.313^{*}$ \\
\hline Age & & & & .190 \\
\hline Tenure & & & & $.231^{*}$ \\
\hline Rank & & & & $.380^{*}$ \\
\hline Step 2: Main effects & .451 & .206 & $11.825 * *$ & \\
\hline Distributive justice & & & & .171 \\
\hline Procedural justice & & & & .182 \\
\hline Interactional justice & & & & $.341 *$ \\
\hline Perceived organisational support & & & & $.353^{*}$ \\
\hline Step 3: Interaction effect & 611 & .159 & $12.629 * *$ & \\
\hline Distributive justice $\times \mathrm{POS}$ & & & & $.260 *$ \\
\hline Procedural justice $\times$ POS & & & & $.378^{*}$ \\
\hline Interactional justice $\times \mathrm{POS}$ & & & & $.405^{*}$ \\
\hline
\end{tabular}

Further, to allow for a more sophisticated exploration of the interrelationship among the variables, hierarchical moderated regression analyses were conducted, the results of which are presented in Table 2. In the first step, gender, status and length of service contributed significantly to the estimated model $\left(F=10.309, p=.0 ; R^{2}=.245\right)$ and explained about $25 \%$ variation in the dependent variable (affective commitment). Gender, tenure and status were significantly related to affective commitment. However, age did not contribute significantly in predicting affective commitment $(\beta=.190, p>.05)$. In step 2 , the study tested for the main effects of POS, distributive justice, procedural justice and interactional justice on affective commitment. These variables were also significant in predicting affective commitment $(F$ $=11.825 . p=.0 ; R^{2}=.451 ; \Delta R^{2}=.206$ ). Together, POS, distributive justice, procedural justice and interactional justice accounted for approximately $45 \%$ variation in affective commitment. In analysing the individual contributions of the independent variables in predicting the dependent variable, the standardised coefficient betas were provided in Table 2. POS and interactional justice significantly predicted affective commitment $(\beta=.231, .380 ; p<.05)$ respectively. Thus, hypothesis $1 \mathrm{c}$ was supported. However, distributive justice and procedural justice were not able to significantly predict affective commitment.

In the third stage, the interactional role of the moderator (POS) was estimated. Inferring from Table 2, the third model was also significant $\left(F=12.629, p=.0 ; R^{2}=.611 ; \Delta R^{2}=.159\right)$, where the interactional variables together accounted for approximately $61 \%$ of the variation in affective commitment. Thus, it implies that POS was able to moderate the relationship between organisational justice and affective commitment. Although distributive justice and procedural justice on their own did not predict affective commitment, the interactional role of POS in the third stage of the model strengthened the predictive ability of all the three dimensions of organisational justice; thus, hypothesis 2 was supported.

The study which used social exchange theory as a guide aimed at investigating organisational justice (distributive, procedural and interactional) and affective commitment and, at the same time, how POS moderated the organisational justice-commitment relationship. Analysis of results provided support for two hypotheses (1c and 2); interactional justice was significantly related to affective commitment, and also, POS significantly moderated organisational justice-commitment relationship. The present results corroborated the findings of Tetteh et al. (2019) which emphasised the roles of interpersonal fairness 
and affective commitment in organisations, where affective commitment increases as a result of an increase in interpersonal fairness and makes the employees have an intention to stay. Also, the findings are in line with established research. For example, Pack et al. (2007) researched on POS, employee satisfaction and retention of student workers in recreational sports department from Mid-Western University. The results from their study indicated that POS had significant relationship with affective commitment, and it accounted for $42.6 \%$ of the variation in affective commitment. The results also support the social exchange theory and imply that exchange relationships do exist among the employees of Ghanaian public universities, wherein the employees interpret the support provided by their employer as a commitment towards them and this, in turn, enhances their commitment to the organisation. Additionally, when the employees perceive the processes used in making decisions in the organisation to be fair, they intend to get more emotionally attached to the company, and this invariably leads to an increased output from the employees. The results are important as committed employees perform beyond their call of duty and are highly motivated to work to the best of their ability. This attitude is essential for improved organisational growth, employee retention and loyalty.

\section{Conclusions}

The findings of this study showed the individual relationship of organisational justice on affective commitment as well the role of (POS) which acted as a buffer in the link between organisational justice and affective commitment were supported (hypotheses $1 \mathrm{c}$ and 2). However, on their own, distributive and procedural justice (hypotheses 1a and 1b) were not significantly related to affective commitment. Accordingly, the study indicates that institutions must have in place policies that ensure fair treatment of employees along the lines of procedures used in managing them, outcomes given to them and the relationship that exists between superiors and subordinates. Additionally, structures must be in the organisation to provide support for the employees to get their commitment. The findings from the research support the need to promote enhanced conditions of work for the employees, as reflected in the opportunities for control and provision of social support. This is essential as POS strongly predicted affective commitment in the present study. Also, perceptions of justice and organisational support when put together strengthened their predictive ability of affective commitment. Thus, there is a need for organisations (management) to direct efforts both on organisational practices and policies to promote the perceptions of fairness and increase efforts to ensure good working conditions in order to achieve the combined benefits of both justice and organisational support.

\section{References}

Ajala, E. M. (2015). The influence of organisational justice on employees' commitment in manufacturing firms in Oyo state, Nigeria: Implications for industrial social work. African Journal of Social Work, 5(1), 92-130.

Allen, N. J., \& Meyer, J. P. (1990). Organizational socialization tactics: A longitudinal analysis of links to newcomers' commitment and role orientation. Academy of management journal, 33(4), 847-858.

Ambrose, M. L., \& Schminke, M. (2009). The role of overall justice judgments in organizational justice research: A test of mediation. Journal of applied psychology, 94(2), 491-500.

Aube, C., Rousseau, V., \& Morin, E. M. (2007). Perceived organizational support and organizational commitment: The moderating effect of locus of control and work autonomy. Journal of managerial Psychology, 22(5), 479-495.

Beugre, C. D., \& Baron, R. A. (2001). Perceptions of systemic justice: The effects of distributive, procedural, and interactional justice. Journal of Applied Social Psychology, 31(2), 324- 339.

Bishop, J. W., Scott, K. D., Goldsby, M. G., \& Cropanzano, R. (2005). A construct validity study of commitment and perceived support variables: A multifoci approach across different team environments. Group \& Organization Management, 30(2), 153-180.

Blau, P. (1964). Exchange and Power in Social Life. New York: Wiley.

Brockner, J. (2002). Making sense of procedural fairness: How high procedural fairness can reduce or heighten the influence of outcome favorability. Academy of management review, 27(1), 58-76.

Bartlett, K. R. (2001). The relationship between training and organizational commitment: A study in the health care field. Human resource development quarterly, 12(4), 335-352. 
Chen, Y. J., Lin, C. C., Tung, Y. C., \& Ko, Y. T. (2008). Associations of organizational justice and ingratiation with organizational citizenship behavior: The beneficiary perspective. Social Behavior and Personality: an international journal, 36(3), 289-302.

Cohen-Charash, Y., \& Spector, P. E. (2001). The role of justice in organizations: A meta-analysis. Organizational behavior and human decision processes, 86(2), 278-321.

Colquitt, J.A., Conlon, D.E., Wesson, M. J. et al. (2001) Justice at the millennium: A meta-analytic review of 25 years of organizational justice research. Journal of Applied Psychology, 86, 425-445.

Cropanzano, R., Bowen, D. E., \& Gilliland, S. W. (2007). The management of organizational justice. Academy of management perspectives, 21(4), 34-48.

Edeh, F. O \& Ugwu, J. N. (2019). Organisational Justice and Employee Commitment of Selected Private Secondary Schools Teachers in Nigeria. International Journal of Management \& Entrepreneurship Research, $1(1), 18-30$.

Eisenberger, R., Fasolo, P., \& LaMastro, D. (1990). Perceived Organizational Support and Employee Diligence, Commitment, and Innovation. Journal of Applied Psychology, 75, 51-59.

Fatt, C. K., Khin, E. W.S. \& Heng, T. N. (2010). The Impact of Organizational Justice on Employee's Job Satisfaction: The Malaysian Companies Perspectives. American Journal of Economics and Business Administration 2 (1), 65-72.

Gyekye, S. A., \& Haybatollahi, M. (2015). Organizational justice: Antecedents and consequences of Ghanaian industrial workers. International Journal of Organization Theory \& Behavior, 18(2), 177-205.

Gouldner, A.W. (1960). The Norm of Reciprocity. American Sociological Review, 25, 161-178.

Hayes, A. (2013). Introduction to mediation, moderation, and conditional process analysis. New York, NY: Guilford.

Jordan, J. S., Turner, B. A., \& Pack, S. M. (2008). Organizational justice as a predictor of perceived organizational support. Res Q Exerc Sport, 79, A92-3.

Lee, O. C., Yusof, A., Geok, S. K., \& Omar, Z. (2017). Volunteerism, Organizational Justice and Organizational Commitment: The Case of Sport Coaches in Malaysian Schools. International Journal of Academic Research in Business and Social Sciences, 7(7), 387-401.

Pack, S. M. (2005). Antecedents and consequences of perceived organizational support for NCAA athletic administrators (Doctoral dissertation, The Ohio State University).

Pack, S. M., Jordan, J. S., Turner, B. A., \& Haines, D. (2007). Perceived organizational support and employee satisfaction and retention. Recreational Sports Journal, 31(2), 95-106.

Perreira, T. A., Berta, W., \& Herbert, M. (2018). The employee retention triad in health care: exploring relationships amongst organisational justice, affective commitment, and turnover intention. J. Clin. Nurs. 27, $1451-1461$

Rego A., \& Cunha, M.P. (2010). Organisational Justice and Citizenship Behaviours: A Study in the Portuguese Cultural Context. Applied Psychology, 59 (3), 404-430.

Spector, P. E. (1997). Job satisfaction: Application, assessment, causes, and consequences (Vol. 3). Sage publications.

Shore, L. M., \& Tetrick, L. E. (1991). A construct validity study of the survey of perceived organizational support. Journal of applied psychology, 76(5), 637.

Sweeney, P. D., \& McFarlin, D. B. (1993). Workers' evaluations of the" ends" and the" means": An examination of four models of distributive and procedural justice. Organizational behavior and human decision processes, 55(1), 23-40. 